\title{
TITLE:
}

\section{CARBONIC ANHYDRASE IN PEARL OYSTER -II. CHANGES OF THE ENZYME ACTIVITY IN RELATION TO GROWTH AND SEASONS-}

$\operatorname{AUTHOR}(S)$ :

Kawai, David Kiyozo

\section{CITATION:}

Kawai, David Kiyozo. CARBONIC ANHYDRASE IN PEARL OYSTER -II. CHANGES OF THE ENZYME ACTIVITY IN RELATION TO GROWTH AND SEASONS-. PUBLICATIONS OF THE SETO MARINE BIOLOGICAL LABORATORY 1955, 5(1): 89-94

\section{ISSUE DATE:}

1955-12-20

URL:

http://hdl.handle.net/2433/174532

RIGHT: 


\title{
CARBONIC ANHYDRASE IN PEARL OYSTER
}

\section{CHANGES OF THE ENZYME ACTIVITY IN RELATION TO GROWTH AND SEASONS ${ }^{1>}$}

\author{
DAVID KIYozo KAWAI \\ Zoological Laboratory, College of Science, Kyoto University, Kyoto
}

With 3 Text-figures

\section{Introduction}

The problem of shell formation in molluscs has hitherto been studied by many investigators, and most of their works were reviewed comprehensively by ROBERTSON (1941). It is now generally conceded that the process of shell formation follows three distinct steps : 1) absorption of calcareous materials into organism, 2) secretion of the shell material from mantle epidermis, 3) transformation of the secreted material to the crystal of calcium carbonate and the organic matrix or the conchiolin which cements the crystal. Recent experiments with radioisotope have shown that the calcium ion in the water is directly absorbed and utilized in shell formation (Bevelander, 1952 ; Wilbur and Jodrey, 1952 ; Abe $e t$ al., 1954; Tanaka and Hatano, 1955).

Although the origin of carbonate radical in shell component is still obscure, a view suggested by RoBERTSON (1941), that metabolic carbon dioxide will be the primary source of the carbonate, may be the most practical one. Furthermore, it is considered that some enzymes, which regulate the production of carbon dioxide and the concentration of bicarbonate and carbonate ion, will play an integral role in the enzymatic system of shell formation. Carbonic anhydrase is one of these enzymes. In the first paper of this series (KAWAI, 1954), it was shown that a considerable amount of the enzyme was present in the tissues of gill on mantle edge. The purpose of the present study is to find out the relationship between the ability of shell formation and carbonic anhydrase activity in this bivalve.

\section{Materials and Methods}

The specimens of the cultured pearl oyster (Pinctada martensii) were obtained from the farm of Nippon Pearl Co. at Shima Peninsula, Mie Prefecture. The age of

1) Reports of Nippon Institute for Scientific Research on Pearls, No. 47.

Publ. Seto Mar. Biol. Lab., V (1), 1955. (Article 6) 
the specimens was estimated from the settling period of the larvae to spat collector and the shell size (Ковау AShI and Tobata, 1949; Yamaguchi, 1949).

Carbonic anhydrase activity was determined by the rapid manometric method of Clakk and Perrin (1951) at $10^{\circ} \mathrm{C}$, and Meldrum-Roughton unit of the enzyme activity was adopted. The concentration of the enzyme solution in a reaction vessel was kept within the range that there was a linear relation between the added amount of the enzyme and observed catalytic effect. After grinding the tissues with a small amount of quartz sand, they were extracted with distilled water in the proportion of $1 \mathrm{ml}$ to each $25 \mathrm{mg}$ of tissue. Other detailed procedure is referred to a previous paper (KAWAI, 1954).

\section{Results}

\section{Growth and enzyme activity.}

The relationship between the enzyme activity of various tissues and the shell growth of pearl oyster is summarized in Figs. 1 and 2. The former result was obtained from materials collected in the middle of June, 1953, and the latter from individuals collected in late October, 1954.

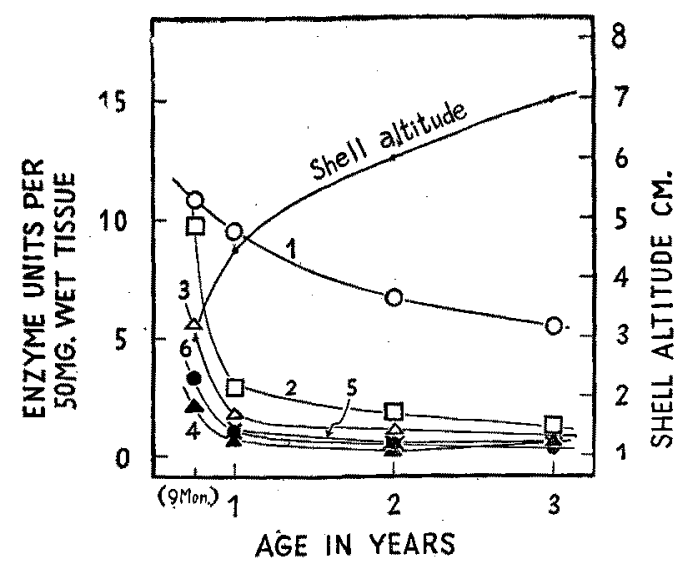

Fig. 1. The relation between carbonic anhydrase activity and shell growth. Materials were collected in June, 1953. The youngest individuals have hatched in early September of last year. Each value is the mean of five to eight individuals. 1. Gill;2. mantle edge ; 3 . outer epidermis of mantle (this tissue adheres to inner surface of shell); 4 . digestive diverticula; 5 . gonad; 6 . adductor muscle.

On all kinds of tissues the highest enzyme activity was found in that of the youngest individual several months after hatching, and its activity was from two to fifteen times that of older ones. Also the enzyme activity per unit weight in various tissues diminished gradually with reduction of the rate of shell growth. These results resemble the result observed in the mantle of oyster (WILBUR and ANDERson, 1950). 


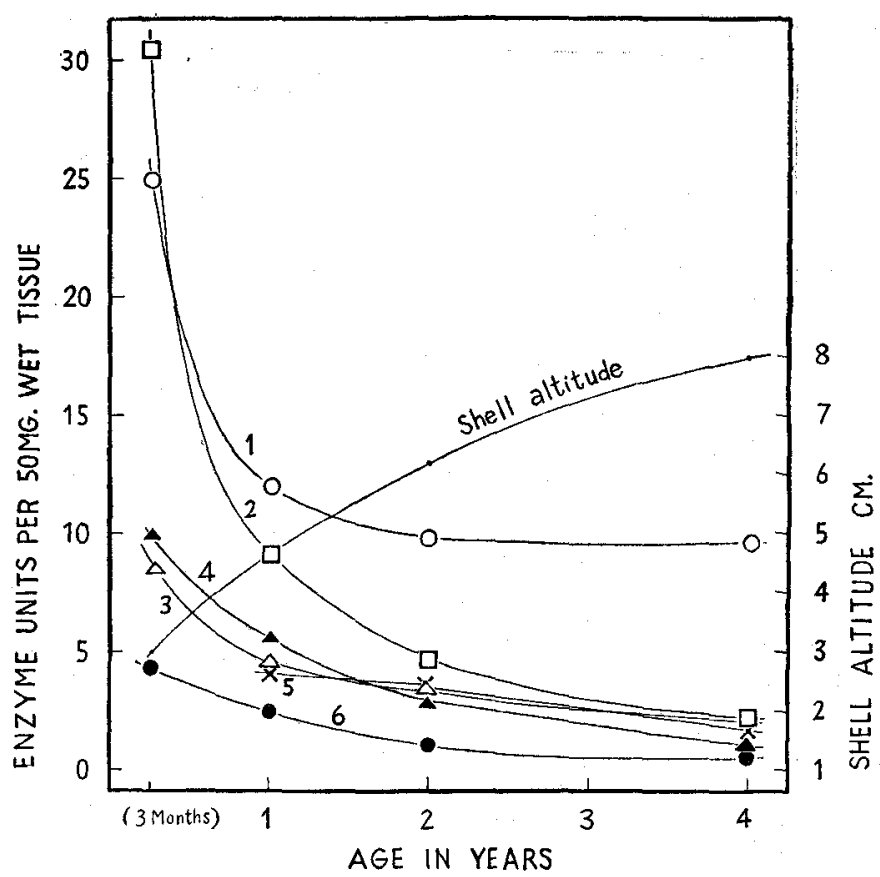

Fig. 2. The relation between carbonic anhydrase activity and shell growth. Materials were collected in October 1954. The youngest bodies have hatched in early. August of this year. 1. Gill; 2 . mantle edge; 3 . outer epidermis of mantle; 4 . digestive diverti. cula; 5 . gonad ; 6 . adductor muscle.

The enzyme activity of gill and mantle edge has shown fairly higher activity than that of the other tissues throughout all individuals. The enzyme activity changes with the transition of seasons, as will be described in the next, but there is no alteration in the general tendency, that the enzyme activity per unit weight diminishes with advancing age, all the year round.

\section{Season and enzyme activity.}

The seasonal changes of marine conditions are quite extensive in the bays where pearl oyster farms are located, and these environmental changes may affect considerably the shell formation and other physiological function of pearl oyster. Several observations were made to know, how the seasonal changes of environmental condition affected carbonic anhydrase activity of various tissues on the specimens of different ages, i.e., several months after hatching, two-year-old and three-year-old. Fig. 3 shows the result of these observations. All the materials were collected in Matoya Bay in Shima district of Mie Prefecture, except those of March which were collected in Ago Bay near Matoya Bay.

There are considerable variation in the enzyme activity throughout the seasons. It seems that the enzyme activity is low in winter and high in summer and autumn. As 


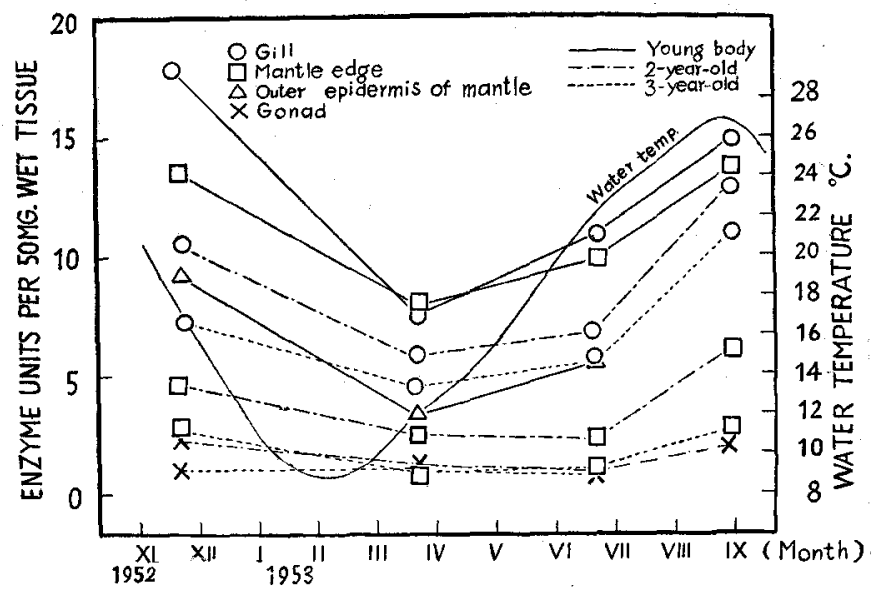

Fig. 3. Seasonal variation of carbonic anhydrase activity. Each value is the mean of five to eight individuals. The curve of water temperature represents the records at two meter depth in Matoya Bay. ${ }^{1)}$

was shown by Kobayashi and ToBata (1949), the growth of pearl oyster is not uniform throughout the year, being rapid from May to November, and slow or stopped entirely from November to May. The water temperature of Matoya Bay rose to $22^{\circ} \mathrm{C}$ in June, ${ }^{1)}$ and the enzyme activity of the youngest, having a little gonad and not yet performing the reproductive function in this year, began to increase (Fig. 3). In contrast with the youngest animal, the enzyme activity of two- or three-year-old one with fully matured gonad showed nearly the winter level in this period. It seems that the enzyme activity of the older organisms begins to increase after the spawning. ${ }^{2)}$

\section{Discussion and Conclusion}

It is very probable that carbonic anhydrase activity of various tissues changes markedly with the change of internal and external conditions of pearl oyster. On the relationship between carbonic anhydrase and shell formation, WILBUR and ANDERSON (1950) and GuTowskA and Mitchell (1945) have made interesting observations. The former authors have shown that carbonic anhydrase activity of Busycon larvae increased markedly at the early stage of shell formation. The latter authors have reported that good layers, producing normal, smooth-shelled eggs, had a carbonic anhydrase activity in their shell gland of over three times that of non-layers and poor layers laying only soft-shelled eggs.

1) The author wishes to record his thanks to Mr. T. Sato, Director of Matoya Oyster Laboratory, who informed him the records of the water temperature in Matoya Bay.

2) In nature, pearl oyster begins to spawn when the water temperature reaches to $25^{\circ} \mathrm{C}$. The spawning normally occurs in late June or early July and usually completes in late August. 
In pearl oyster, it was found that carbonic anhydrase activity of various tissues was very low in some individuals (Table 1), which had no small scaly process at the shell edge because of ceasing the shell growth. Although the radical cause on the ceasing of the shell formation is not yet well known, it may be due to general debility of the bodies, in which the outer epidermis of mantle appears to be transparent owing to the disappearance of glycogen layer. ${ }^{1)}$

Table 1. Carbonic anhydrase activity of various tissues of pearl oyster related to productivity of the scaly process at the shell edge.

\begin{tabular}{l|c|c}
\hline \multirow{2}{*}{} & \multicolumn{2}{|c}{ Enzyme unit per $50 \mathrm{mg}$ wet tissue } \\
\cline { 2 - 3 } & Normal bodies & Abnormal bodies \\
\hline \multirow{2}{*}{ Gill } & 10.6 & 5.9 \\
Mantle edge & 4.5 & 1.7 \\
Outer epidermis of mantle & 1.7 & 1.3 \\
Gonad & 2.9 & 2.1 \\
Digestive diverticula & 2.5 & 1.7 \\
Adductor muscle & 0.3 & trace \\
\hline
\end{tabular}

Normal bodies have a large number of small scaly process at the shell edge, but abnormals haven't such scaly process. Materials were collected in November, 1952. The age was about two-year-old. Each value is the mean of 10 individuals.

It is of interest that such reduction of the enzyme activity occurs conspicuously in the tissues of mantle edge, as nearly one-third of that in normal bodies, which will play an important role in shell formation.

It seems that the alteration of carbonic anhydrase activity with advancing ages is proportional to the ability of shell formation. This reduction of the enzyme activity with age may be regarded as a sort of biochemical senility. However, we must consider furthermore that the change may be due to relative increase of the cell not directly involving the enzyme, as previously pointed out by WILBUR and ANDERson (1950) on the mantle of oyster.

Although the physiological function of the gill in this bivalve is not clear, it is assumed that the ciliated tissue performes both respiratory function and absorption of the salt in the water, because a large amount of carbonic anhydrase is present in the tissue and it actively absorbes the calcium ion in the water (TANAKa and Hatano, 1955).

As is shown in Fig. 3, the enzyme activity changes with season and reproductive function. The variation of the enzyme activity seems to correspond with the rate of shell growth (KOBAYASH and TOBATA, 1949) and secreting ability of byssus changing with seasons (КовауASHI, 1951). From the present results, it can be concluded that carbonic anhydrase activity of pearl oyster is regulated by the internal and external factors of the organism, and that the enzyme activity is closely related to the activity of shell formation.

1) In normal bodies, this outer epidermis is white and reserves large amount of glycogen (ASHIKAGA, 1949). 


\section{Summary}

1. Carbonic anhydrase activity of various tissues of pearl oyster (Pinctada martensii) 'changes markedly with transition of various internal and environmental factors of the organism, such as growth, reproductive function and seasons.

2. In all tissues, the highest activity is found in the youngest individuals several months after hatching, and the enzyme activity reduces gradually with advancing age.

3. As to seasonal variations, the enzyme activity is generally low in winter season and increases during the period from summer to autumn.

5. In just prior to the spawning, the enzyme activity of two- or three-year-old individuals with fully matured gonad shows nearly winter level, but that of several months old having a little gonad and no spawning in this year, shows already a considerable increase.

The author is greatly indebted to Prof. D. MiYadi, Lecturer K. ONo of Kyoto University and Dr. Y. MAISUI, Director of Nippon Institute for Scientific Research on Pearls for their cordial help and valuable advices. He also wishes to acknowledge his thanks to Mr. K. IsowA of Nippon Pearl Co. for providing materials in experiments.

\section{LITERATURE}

ABE, Y., KADO, Y. et al. 1954. Measurements of biochemical deposition of calcium by oyster kept in sea water of three different calcium content labeled with $\mathrm{Ca}^{45}$. Jour. Sci. Hiroshima Univ., Ser. A, vol. 18, pp. 249-252.

Ashikaga, C. 1949. Biochemical studies on pearl oyster (Pinctada martensii). III. On the glycogen content in relation to portions and to sexes. Jour. Agr. Chem. Soc. Jap., vol. 23, pp. 65-68. (in Japanese with English abstract.)

Bebel ANDER, G. 1952. Calcification in molluscs. III. Intake and deposition of $\mathrm{Ca}^{45}$ and $\mathrm{P}^{32}$ in relation to shell formation. Biol. Bull., vol. 102, pp. 9-15.

Clark, A. and Perrin, D. D. 1951. Re-investigation of the question of activators of carbonic anhydrase. Biochem. Jour., vol. 48, pp. 495-502.

Gutowska, M. S. and Mrtchell, C. M. 1945. Carbonic anhydrase in the calcification of the egg shell. Poultry Sci., vol. 24, pp. 159-167.

KAWAI, D. K. 1954. Carbonic anhydrase in pearl oyster. I. Distribution and some properties of the enzyme. Mem. Coll. Sci., Univ. Kyoto, Ser. B, vol. 21, pp. 39-44.

Kobayashi, S. 1951. Annual periodicity of the power of byssus secretion in pearl oyster. Jour. Fuji Pearl Institute, vol. 2, pp. 7-12. (in Japanese.)

Kobayashi, S. and Tobata, M. 1949. Studies on culture of pearl. II. Activity of pearl oyster in winter. Bull. Jap. Soc. Sci. Fisheries, vol. 14, pp. 196-199. (in Japanese with English synopsis.)

Robertson, J. D. 1941. The function and metabolism of calcium in the invertebrata. Biol. Rev., vol. 16, pp. 106-133.

TANAKA, S. and HATANO, H. 1955. Biochemical studies on pearl. IV. On the uptake of radioactive calcium by pearl oyster and its deposition on the pearl and the shell. Jour. Chem. Soc. Jap., vol. 76, pp. 602-605. (in Japanese.)

WilBUR, K. M. and ANDERSON, N. C. 1950. Carbonic anhydrase and growth in the oyster and busycon. Biol. Bull., vol. 98, pp. 19-24.

WiLBUR, K. M. and Jodrey, L. H. 1952. Studies on shell formation. I. Measurement of the rate of shell formation using $\mathrm{Ca}^{45}$. Biol. Bull., vol. 103, pp. 269-276.

YAMAGUCHI, M. 1949. Cited from Natural Resources Section Report (published by G. H. Q. Allied Forces). Pearl Culture in Japan, p. 25. 